\title{
Detection of enterovirulent Escherichia coli associated with diarrhoea in Seville, Southern Spain, with non- radioactive DNA probes
}

\author{
C. M. A. RADEMAKER* $\dagger^{\dagger}$, L. MARTINEZ-MARTINEZ $\S$, E. J. PEREA $\S$, M. JANSZE* $*$ A. C. FLUIT* $\ddagger$, \\ J. H. GLERUM $\dagger$ and J. VERHOEF*
}

*Eijkman Winkler Laboratory for Medical Microbiology, †Department of Hospital Pharmacy, and $\ddagger U$-gene Research, University Hospital Utrecht, PO Box 85,500, 3508 GA Utrecht, The Netherlands, and §Departamento de Microbiologia, Universidad de Sevilla, Sevilla, Spain

\begin{abstract}
Summary. To assess the role of diarrhoeagenic Escherichia coli in Southern Spain, faecal samples from 135 patients with diarrhoea and 40 healthy subjects from Seville, Andalusia, were investigated. In this prospective study, enterovirulent $E$. coli were identified by hybridisation with five non-radioactive DNA probes specific for enterotoxigenic $E$. coli (ETEC), enteropathogenic $E$. coli (EPEC) and verocytotoxin-producing $E$. coli (VTEC). Probe-positive strains were isolated from four patients $(3 \%)$ with diarrhoea and from none of the healthy controls. Two patients harboured ETEC and two patients had EPEC probepositive strains in their faeces. No VTEC were isolated during this study. Salmonella spp. were the most frequently identified enteric pathogens, accounting for $10 \%$ of the cases, followed by Campylobacter jejuni (3\%) and diarrhoeagenic E. coli (3\%). This study indicates that enterovirulent $E$. coli play a modest role in the aetiology of diarrhoea among the indigenous population of Southern Spain.
\end{abstract}

\section{Introduction}

Escherichia coli is generally regarded as a benign commensal of the intestinal tract in man. However, within this species, there are pathogenic strains that are associated with intestinal infections. ${ }^{1}$ These strains may be termed enterovirulent $E$. coli (EVEC). ${ }^{2}$ Studies of the pathogenic mechanisms involved permit the separation of EVEC into four groups which differ in epidemiology and clinical picture. ${ }^{1,2}$ Enterotoxigenic E. coli (ETEC) causes diarrhoea in adults and children in developing countries and in travellers to these areas. $^{3-6}$ The role of ETEC in diarrhoea amongst the indigenous population of European countries has been less clearly defined. Verocytotoxic $E$. coli (VTEC) has been identified as a significant cause of haemorrhagic colitis and haemolytic uraemic syndrome in the United Kingdom, North America, Czechoslovakia and Germany, in occasional outbreaks as well as in sporadic cases. $^{7-12}$ Enteropathogenic $E$. coli (EPEC) is associated with outbreaks of acute diarrhoea in neonates. ${ }^{13,14}$ Hill et al. have recently reported individual cases of serious chronic diarrhoea associated with EPEC in children after the neonatal period. ${ }^{15}$ The last group is formed by the enteroinvasive $E$. coli (EIEC). The prevalence of EIEC is low. ${ }^{1}$
In the past, identification of $E$. coli strains causing diarrhoea was possible only by testing culture supernates in tissue culture in combination with serotyping. The use of DNA probes has greatly facilitated detection. In a previous study we described a simplified and accurate hybridisation assay for detecting ETEC, VTEC and EPEC directly in stool smears with a set of five non-radioactive DNA fragment probes. ${ }^{16}$ Here we report the results of a prospective study of the frequency of EVEC in subjects with and without diarrhoea in Seville, Southern Spain.

\section{Materials and methods}

\section{Study population}

Stool specimens from 135 subjects ( 100 children and 35 adults) with diarrhoea and control faecal specimens from 40 subjects ( 14 children and 26 adults) without diarrhoea were collected in Seville, Andalusia, during 3 weeks in September 1991. Faecal samples were obtained from in-patient and out-patient settings.

\section{Laboratory studies}

For the identification of EVEC c. $1 \mathrm{~g}$ of faeces was placed in transport medium containing cysteine hydrochloride (Fluka, Switzerland), peptone (Oxoid) 
and yeast extract (Merck, Germany); after homogenisation, these were stored at $4^{\circ} \mathrm{C}$ for a maximum of 15 days. Diarrhoeal specimens were cultured for common intestinal pathogens including Salmonella spp., Shigella spp., Yersinia spp., Vibrio spp., Aeromonas spp., Plesiomonas spp., Campylobacter spp. and were examined for Giardia lamblia by standard bacteriological techniques. Diarrhoeal samples and control samples were cultured for EVEC. Samples $(100 \mu \mathrm{l})$ of a $10^{2}$ or $10^{3}$ dilution $(\mathrm{w} / \mathrm{v})$ of faeces in transport medium were plated out on MacConkey agar plates without neutral red. After overnight incubation at $30^{\circ} \mathrm{C}$, bacteria were replica-plated on to Z-probe filters (BioRad Laboratories). Bacteria were lysed and their DNA was fixed on the filters as described previously. ${ }^{16}$

\section{DNA probe assay}

Recombinant plasmids pWD299, pSLM004 and pJPN 16 encoding for ETEC LT, ${ }^{17}$ ETEC STaII ${ }^{18}$ and EPEC ${ }^{19}$ respectively, were used as donors of the probes and were kindly provided by $\operatorname{Dr}$ P. J. Sansonetti, Institut Pasteur, Paris. Strains 6OR746 and 6OR363, carrying recombinant plasmids encoding VT1- and VT2-specific sequences to identify VTEC $^{20,21}$ were kindly donated by Dr H. R. Smith, Central Public Health Laboratory, London. Probes were labelled with digoxigenin (Boehringer, Mannheim, Germany) by the polymerase chain reaction (PCR). The primers used for the generation of the probes, their length, the appropriate hybridisation temperatures, the composition of the PCR reaction mixture and hybridisation and detection methods have been described previously. ${ }^{16}$

\section{Serotyping}

Probe-positive $E$. coli strains were serotyped for the presence of $\mathrm{O}$ and $\mathrm{K}$ antigens by means of a mechanised microtechnique with all available $\mathrm{O}(\mathrm{O} 1-171)$ antigens and $\mathrm{O}: \mathrm{K}$ antisera against the $\mathrm{K}$ antigens usually associated with each $\mathrm{O}$ antigen. ${ }^{22}$

\section{Antibiotic resistance patterns}

Antibiotic susceptibility of probe-positive isolates was determined by an agar diffusion method with ciprofloxacin, amoxycillin, co-amoxyclav doxycycline and co-trimoxazole tablets (Rosco, Taastrup, Denmark)

\section{Results}

The isolation rates of enteric pathogens among patients with diarrhoea are shown in the table. EVEC
Table. Frequency of isolation of enteropathogenic bacteria from faeces of 135 patients with diarrhoea in Seville, Southern Spain

\begin{tabular}{lc}
\hline Enteropathogens & $\begin{array}{c}\text { Number }(\%) \\
\text { of patients }\end{array}$ \\
\hline Salmonella spp. & $14(10 \%)$ \\
Enterovirulent $E$. coli & $4(3 \%)$ \\
C. jejuni & $4(3 \%)$ \\
G. lamblia & $1(0.7 \%)$ \\
Total & $23(17 \%)$ \\
\hline
\end{tabular}

were isolated from four $(3 \%)$ patients with diarrhoea and from none of the control group.

One or more enteropathogenic micro-organisms were isolated from $23(17 \%)$ of 135 faecal samples from subjects with diarrhoea. Salmonella spp. were detected from $14(10 \%)$ patients, (10 children and four adults) and $C$. jejuni from four $(3 \%)$ children. $G$. lamblia was detected in one $(0.7 \%)$ patient. Three ETEC strains were isolated from two children with diarrhoea. One ETEC strain produced heat-labile toxin (ETEC LT) and was of serotype O25. Two different ETEC strains producing heat-stable toxin (ETEC ST) were isolated from another child; they belonged to the serotypes $\mathrm{O} 115$ and O15. One child and one adult with diarrhoea harboured EPEC probepositive strains in their faeces. The serotypes of these strains were $\mathrm{O} 127$ and $\mathrm{O} 23 \mathrm{~K} 18$, respectively. No other $E$. coli serotypes were detected in the faecal samples from which the ETEC LT (serotype O25) and the EPEC (serotype O127) strains were isolated. On the other hand, the ETEC ST (serotypes O15 and O115) and the EPEC (serotype O23K 18) strains comprised only $15-30 \%$ of the $E$. coli flora tested. During the study period, no VTEC strains were identified.

With respect to antibiotic susceptibility patterns, the EPEC strains and the ETEC LT strain were susceptible to all antibiotics tested. Both ETEC ST strains were resistant to amoxycillin and co-trimoxazole.

\section{Discussion}

Many studies have identified ETEC as the most common cause of travellers' diarrhoea in endemic areas in Africa, Asia and Latin America. ${ }^{5,23,24}$ In a recent study among Swedish travellers with diarrhoea, the isolation rate of ETEC was $20 \%$ in travellers visiting developing countries versus $13 \%$ in those travelling to Southern Europe. ${ }^{25}$ As far as we know, the importance of ETEC as a cause of diarrhoea in the indigenous population of Southern Europe has been less well defined. In this prospective study, the isolation rate of ETEC was $2 \%$ in 100 children with diarrhoea in Seville in September 1991 (mean daily temperature $38^{\circ} \mathrm{C}$ ). The affected children were 6 and 7 years old. Blanco et al. reported an isolation rate of $3.9 \%$ for ETEC in children with diarrhoea in North-Western 
Spain. ${ }^{26}$ In their study, ETEC were isolated more frequently from children with diarrhoea who were $<1$ month of age than from older children. The investigators suggested that ETEC constituted an important cause of neonatal diarrhoea and, moreover, that ETEC infections may manifest as nosocomial outbreaks. We did not test faecal samples from neonates. However, when we compare our age group to the similar age group of Blanco, the isolation rates of ETEC are in the same order of magnitude. Two EPEC probe-positive strains were detected. The EPEC strain of serotype $\mathrm{O} 127$ was isolated from a child. This serotype belongs to classical EPEC serotypes and is associated with diarrhoea in children. ${ }^{1}$ The EPEC of serotype $\mathrm{O} 23 \mathrm{~K} 18$ was detected in the stool of an adult with diarrhoea and does not belong to the classical serotypes of the EPEC species. Interestingly, we have isolated EPEC probe-positive strains with the same serotype from three adults with diarrhoea and from one adult without symptoms during an investigation

\section{References}

1. Levine MM. Escherichia coli that cause diarrhea: enterotoxigenic, enteropathogenic, enteroinvasive, enterohemorrhagic, and enteroadherent. $J$ Infect Dis 1987; 155 : 377-389.

2. Lupski JR, Feigin RD. Molecular evolution of pathogenic Escherichia coli. J Infect Dis 1988; 157: 1120-1123.

3. Sack DA, Kaminsky DC, Sack RB et al. Prophylactic doxycycline for travelers' diarrhea: results of a prospective double-blind study of Peace Corps volunteers in Kenya. $N$ Engl J Med 1978; 298: 758-763.

4. Sack RB, Froehlich JL, Zulich AW et al. Prophylactic doxycycline for travelers' diarrhea: results of a prospective double-blind study of Peace Corps volunteers in Morocco. Gastroenteroly 1979; 76: 1368-1373.

5. Black RE. Pathogens that cause travelers' diarrhea in Latin America and Africa. Rev Infect Dis 1986; 8 Suppl 2: S131-S135.

6. Cravioto A, Reyes RE, Ortega R, Fernández G, Hernández R López D. Prospective study of diarrhoeal disease in a cohort of rural Mexican children: incidence and isolated pathogens during the first two years of life. Epidemiol Infect 1988; 101 : 123-134.

7. Smith HR, Rowe B, Gross RJ, Frey NK, Scotland SM. Haemorrhagic colitis and vero-cytotoxin-producing Escherichia coli in England and Wales. Lancet 1987; 1: 1062-1065.

8. Tarr PI, Neill MA, Clausen CR, Watkins SL, Christie DL, Hickman RO. Escherichia coli O157:H7 and the hemolytic uremic syndrome: importance of early cultures in establishing the etiology. $J$ Infect Dis 1990; 162: 553-556.

9. Fitzpatrick MM, Shah V, Trompeter RS, Dillon MJ, Barratt TM. Long term renal outcome of childhood haemolytic uraemic syndrome. $B M J 1991$; 303: 489-492.

10. Symonds J. Haemorrhagic colitis and Escherichia coli $\mathrm{O} 157-\mathrm{a}$ pathogen unmasked. BMJ 1988; 296: 875-876.

11. Bielaszewská M, Srámkoá L, Janda J, Bláhová K, Ambrozová H. Verotoxigenic (enterohaemorrhagic) Escherichia coli in infants and toddlers in Czechoslovakia. Infection 1990; 18: $352-356$.

12. Bitzan M, Moebius E, Ludwig K, Müller-Wiefel DE, Heesemann J, Karch H. High incidence of serum antibodies to Escherichia coli $\mathrm{O} 157$ lipopolysaccharide in children with hemolytic-uremic syndrome. J Pediatr 1991; 119: 380-385.

13. Gerards LJ, Hennekam RCM, Van Dijk WC, Roord JJ, Fleer A An outbreak of gastroenteritis due to Escherichia coli $\mathrm{O} 142$ H6 in a neonatal department. J Hosp Infect 1984; 5: 283-288. into the role of diarrhoeagenic $E$. coli in the Netherlands (unpublished data).

In the present study, filters with $50-500 \mathrm{E}$. coli colonies were hybridised with probes. ${ }^{16}$ This method provides rough information about the quantity of pathogens present in the stool. The two ETEC ST strains and one of the EPEC isolates were not present as pure cultures in the stool and would not have been diagnosed had only one-to-five $E$. coli colonies, isolated at random from each sample, been examined. In this study, the isolation rate of Salmonella spp. was $10 \%$. Similar rates were demonstrated in previous studies. ${ }^{26,27}$ In agreement with these results, Salmonella spp. were identified in stools of Swedish travellers more often $(26 \%)$ than ETEC $(13 \%)$ after travel to Southern Europe. ${ }^{25}$

This study indicates that enterovirulent $E$. coli play a modest role in the aetiology of diarrhoea in the indigenous population of Seville. The frequency was $3 \%$ and was similar to the isolation rate of $C$. jejuni.

14. Levine MM, Edelman R. Enteropathogenic Escherichia coli of classic serotypes associated with infant diarrhea: epidemiology and pathogenesis. Epidemiol Rev 1984; 6: 31-51.

15. Hill SM, Philips AD, Walker-Smith JA. Enteropathogenic Escherichia coli and life threatening chronic diarrhoea. Gut 1991; 32: 154-158.

16. Rademaker CMA, Wolfhagen MJHM, Jansze $\mathrm{M}$ et al. Digoxigenin labelled DNA probes for rapid detection of enterotoxigenic, enteropathogenic and vero-cytotoxin producing Escherichia coli in faecal samples. $J$ Microbiol Methods 1992; 15: 121-127.

17. Dallas WS, Gill DM, Falkow S. Cistrons encoding Escherichia coli heat-labile toxin. $J$ Bacteriol $1979 ; 139$ : 850-858.

18. Moseley SL, Hardy JW, Huq MI, Echeverria P, Falkow S. Isolation and nucleotide sequence determination of a gene encoding a heat-stable enterotoxin of Escherichia coli. Infect Immun 1983; 39: 1167-1174.

19. Nataro JP, Scaletsky ICA, Kaper JB, Levine MM, Trabulsi LR. Plasmid-mediated factors conferring diffuse and localized adherence of enteropathogenic Escherichia coli. Infect Immun 1985; 48: 378-383.

20. Willshaw GA, Smith HR, Scotland SM, Rowe B. Cloning of genes determining the production of Vero cytotoxin by Escherichia coli. J Gen Microbiol 1985; 131 : 3047-3053.

21. Willshaw GA, Smith HR, Scotland SM, Field AM, Rowe B. Heterogeneity of Escherichia coli phages encoding Vero cytotoxins: comparison of cloned sequences determining $\mathrm{T} 1$ and T2 and development of specific gene probes. $J$ Gen Microbiol 1987; 133: 1309-1317.

22. Guinée PAM, Agterberg CM, Jansen WH. Escherichia coli O antigen typing by means of a mechanized microtechnique. Appl Microbiol 1972; 24 : 127-131.

23. Taylor DN, Echeverria P. Etiology and epidemiology of traveler's diarrhea in Asia. Rev Infect Dis 1986; 8 Suppl 2: S136-S141.

24. Rademaker CMA, Krul MRL, Jansen WH et al. Analysis of Escherichia coli isolates from subjects with travellers' diarroea using DNA probes and serotyping. Eur $J$ Clin Microbiol Infect Dis 1991; 10: 625-629.

25. Jertborn M, Svennerholm AM. Enterotoxin-producing bacteria isolated from Swedish travellers with diarrhoea. Scand J Infect Dis 1991; 23 : 473-479.

26. Blanco J, González EA, Blanco M et al. Enterotoxigenic Escherichia coli associated with infant diarrhoea in Galicia, north-western Spain. J Med Microbiol 1991; 35: 162-167.

27. Velasco AC, Mateos ML, Más G, Pedraza A, Díez M, Gutiérrez A. Three-year prospective study of intestinal pathogens in Madrid, Spain. J Clin Microbiol 1984; 20: 290-292. 